\title{
1,3-di(benzo[d]oxazol-5-yl)urea acts as either adventitious rooting adjuvant or xylogenesis enhancer in carob and pine microcuttings depending on the presence/absence of exogenous indole-3-butyric acid
}

\author{
Ada Ricci ${ }^{1}$ - Enrico Rolli ${ }^{1}$ Federica Brunoni ${ }^{1}$. Lucia Dramis ${ }^{1}$ Ermanno Sacco ${ }^{2}$. \\ Laura Fattorini $^{3} \cdot$ Barbara Ruffoni $^{2} \cdot$ Carmen Díaz-Sala $^{4} \cdot$ Maria Maddalena Altamura $^{3}$
}

Received: 22 February 2016/ Accepted: 17 May 2016/Published online: 27 May 2016

(c) The Author(s) 2016. This article is published with open access at Springerlink.com

\begin{abstract}
Asexual propagation in Ceratonia siliqua L. (carob), species of economic value, is difficult because of adventitious rooting recalcitrance. In Pinus radiata adventitious rooting of hypocotyl cuttings is enhanced by two urea-derivatives, 1,3-di(benzo[ $d]$ oxazol-5-yl)urea (5BDPU) and 1,3-di(benzo[ $d]$ oxazol-6-yl)urea (6-BDPU), combined with exogenous indole-3-butyric acid (IBA). The research was aimed to define the role of these ureaderivatives in adventitious root (AR) formation of carob, and to identify morphogenic roles induced in carob, but also in pine, a distantly-related forest species. In carob, 5-BDPU $(10 \mu \mathrm{M})$ highly promoted AR formation in combination with IBA $(1 \mu \mathrm{M})$ when applied for 3 days, followed by a transfer onto hormone free medium (HF) up to culture end (4 weeks). IBA alone $(1 \mu \mathrm{M})$ was more effective than IBA + kinetin (Kin, $10 \mathrm{nM}$ ), whereas Kin alone and 5-BDPU alone were not AR-inductive. The histological analysis showed that the cambial cells initiated the ARs, and similar numbers of AR-primordia were
\end{abstract}

Electronic supplementary material The online version of this article (doi:10.1007/s11240-016-1010-9) contains supplementary material, which is available to authorized users.

Maria Maddalena Altamura

mariamaddalena.altamura@uniroma1.it

1 Dipartimento di Bioscienze, Università di Parma, Parco Area delle Scienze 11/A, 43124 Parma, Italy

2 CREA Ornamental Plant Research Unit, Corso degli Inglesi 508, 18038 Sanremo, IM, Italy

3 Dipartimento di Biologia Ambientale, Sapienza Università di Roma, Piazzale Aldo Moro 5, 00185 Rome, Italy

4 Departamento de Ciencias de la Vida, Universidad de Alcalá, Carretera de Barcelona Km 33.6, Alcalá de Henares, 28805 Madrid, Spain visible at day 12 , independently of the AR-inductive treatment (i.e., IBA, IBA + 5-BDPU, IBA + Kin). No cutting treated with Kin alone, and rare HF ( \pm 5 -BDPU)treated ones, showed AR-primordia at day 12. The number of AR-forming explants increased under IBA + 5-BDPU. By contrast, the cambial cells were stimulated to initiate deuteroxylem instead of ARs under 5-BDPU alone. The histological analysis in pine microcuttings treated with IBA and/or 5-BDPU at the same concentrations confirmed that 5-BDPU applied alone enhanced xylogenesis, highlighting that this urea-derivative exhibits a dual morphogenic role being involved in the switching between adventitious rooting and xylogenesis depending on the presence of exogenous auxin in both species.

Keywords Adventitious rooting · Carob - Indole-3-butyric acid $\cdot$ Pine $\cdot$ Urea derivatives $\cdot$ Xylogenesis

$\begin{array}{ll}\text { Abbreviations } \\ \text { AR } & \text { Adventitious root } \\ \text { 5-BDPU } & \text { 1,3-di(benzo }[d] \text { oxazol-5-yl)urea } \\ \text { 6-BDPU } & \text { 1,3-di(benzo }[d] \text { oxazol-6-yl)urea } \\ \text { HF } & \text { Hormone-free } \\ \text { IAA } & \text { Indole-3-acetic acid } \\ \text { IBA } & \text { Indole-3-butyric acid } \\ \text { Kin } & \text { Kinetin } \\ \text { SCL } & \text { SCARECROW-LIKE }\end{array}$

\section{Introduction}

It is well known that plants may regenerate parts of their body, e.g. adventitious roots (ARs), or even a new organism, e.g., embryos, through cellular dedifferentiation and re-differentiation events involving different pathways and 
strategies of regeneration. This occurs because the fate of somatic cells can be switched into new developmental programmes by the activities of pre-existing, or de novo formed, stem cells, with the mechanisms enabling this developmental plasticity not fully understood. Adventitious rooting is a post-embryonic process consisting of successive developmental phases, which occurs naturally or can be induced by abiotic stresses, i.e., injuries and/or floods, allowing plant survival after sudden environmental changes (Li et al. 2009). In all cases, AR formation involves the canalization of somatic cells into a new organogenic program. Some endogenous factors, hormones and/or hormonal balance, tissue maturity, expression of specific regulatory genes, have been recognized as fundamental factors in this regeneration scenario (Busov et al. 2009; Abarca and Diaz-Sala 2009; da Costa et al. 2013; Della Rovere et al. 2013, 2015; Legué et al. 2014; Pacurar et al. 2014; Welander et al. 2014). Xylogenesis consists of the formation of xylary cells. It is a morphogenic program induced by auxin alone or auxin-plus-cytokinin, depending on the species and system (Fukuda 1997). Xylogenesis may occur as an alternative program to adventitious rooting, as in the rooting-recalcitrant cuttings of walnut and tobacco rac mutant (Reverberi et al. 2001; Faivre-Rampant et al. 2003). However, it may also occur concomitantly with adventitious rooting, as in tobacco and Arabidopsis thin cell layers (TCLs), with the prevalence of one program on the other depending on various factors, e.g., calcium ion and jasmonate concentration in the medium (Falasca et al. 2004; Fattorini et al. 2009). In Arabidopsis, it has been recently demonstrated that the same cells reactivated by the auxin treatments to re-differentiate and to produce ARs in planta, and in TCLs, are also able to initiate xylogenesis, with SHORTROOT and SCARECROW transcription factors, and AUX1 auxin-influx carrier, controlling the switching between the programs (Della Rovere et al. 2015).

Adventitious rooting is a major program in horticultural practices, because vegetative propagation is a widely spread technique to multiply plants producing clonal populations (Hartmann et al. 1990). Unfortunately, plant species show different rooting capacity and many of them, especially woody species, are recalcitrant to form ARs (Altamura 1996). Therefore, in commercial propagation of difficult-to-root species, limited adventitious rooting may negatively affect the survival rate of the micropropagated plantlets during the acclimatization phase, resulting into remarkable economic losses. To overcome this situation, micropropagation programmes have greatly increased, as in vitro techniques allow controlling culture conditions, including environmental parameters such as light and temperature. This gives the opportunity to investigate the effects of culture-medium components, avoiding the interference of seasonal changes (George 1993). The study of the effects of exogenously added natural or synthetic auxins, in the presence or absence of other plant growth regulators, e.g., kinetin (Kin), and of auxin-transport inhibitors or influx/efflux carriers, has resulted in the demonstration that endogenous auxin (indole-3-acetic acid) is the indubitable central player in controlling and stimulating AR formation (Della Rovere et al. 2013, 2015; Pacurar et al. 2014). Besides, a wide range of chemicals have been used in combination with auxin looking for higher rooting performance and reduction of deleterious effects of auxin treatment, i.e., formation of wide callus or emergence of stunted or malformed roots (Welander and Huntrieser 1981; Cheng et al. 1992; Orlikowska 1992; Rugini et al. 1993; Auderset et al. 1997). N,N'-bis-(2,3-methylenedioxyphenyl)urea (2,3-MDPU), N,N'-bis-(3,4-methylenedioxyphenyl)urea (3,4-MDPU), and, more recently 1,3di(benzo[d]oxazol-5-yl)urea (5-BDPU) and 1,3di(benzo[d]oxazol-6-yl)urea (6-BDPU), all urea derivatives, are among these chemicals (Ricci et al. 2003, 2006, 2008; Brunoni et al. 2014). In particular, based on structure-activity studies, Ricci et al. (2003, 2008) reported that 2,3-MDPU and 3,4-MDPU enhance AR formation in Malus pumila Mill. M26 stem slices and in Pinus radiata $\mathrm{D}$. Don stem cuttings, in the presence of exogenous auxin. 5-BDPU and 6-BDPU also exert an endogenous and/ or exogenous auxin-adjuvant effect on AR formation in distantly related plants and systems, i.e., mung bean shoots, apple stem slices, Arabidopsis seedlings and Pinus radiata hypocotyl cuttings, even if they have no auxin- or cytokinin-like activity (Ricci et al. 2006; Brunoni et al. 2014).

Carob tree, Ceratonia siliqua L., belonging to Fabaceae family, is an important species of Mediterranean eco-systems, growing in marginal calcareous soils. Carob grows well even in dry climates, and trees have been inter-planted with olives, grapes, almonds and barley in low intensity farming systems. It is well known for its edible seeds that are used as chocolate substitute. However, the main economic interest is seed production for gum extraction. Owing to the low orchard management requirements, carob tree is suitable for part-time labour and shows potential for extending planting to subtropical regions. The trees are also useful as ornamentals, for landscape and urban architecture, windbreaks and reforestation of degraded areas in the Mediterranean basin (Sakcali and Ozturk 2004). The asexual propagation of carob superior genotypes is performed by grafting or cuttings, but both systems give poor results. To fulfil the increased market request, in vitro micropropagation starting from adult plants has been reported, mainly for Portuguese selections with industrial interest (Sebastian and McComb 1986; Romano et al. 2002; Brugaletta et al. 2009). The rooting phase was tentatively induced by different approaches, i.e., in vitro culture on a traditional agar-based medium containing indole- 
3-butyric acid (IBA) (Sebastian and McComb 1986), basal dipping of shoots in IBA followed by culture onto a hormone free (HF) medium (Romano et al. 2002), and application of several carbon sources (Custodio et al. 2004). Difficulties were often reported depending on the genotype.

As large-scale vegetative propagation depends on the rooting ability of micropropagated shoots, a research was carried out to improve not only the in vitro rooting phase, but also the following ex vitro acclimatisation phase of carob difficult-to-root micropropagated cuttings by the use of 5-BDPU or 6-BDPU, because important adventitious rooting adjuvant compounds (Ricci et al. 2006; Brunoni et al. 2014). This research is the first attempt to utilise these compounds to enhance adventitious rooting in this valuable woody angiosperm, and to compare histologically results with those obtained from the cuttings of Pinus radiata, a distantly-related woody gymnosperm, for which both compounds are AR-effective (Brunoni et al. 2014).

A rooting protocol was optimized, in terms of low auxin concentration, reduction of callus formation, high rooting performance, and high survival rate during ex vitro acclimatization. It required the simultaneous supplementation of IBA and 5-BDPU, at specific concentrations, in the darkness for 3 days only. The effectiveness of IBA + 5-BDPU treatment was validated comparing with the simultaneous supplementation of IBA and Kinetin (Kin). The latter is a synthetic adenine derivative showing cytokinin-like activity frequently used to induce adventitious rooting in combination with IBA (Tran Thanh Van et al. 1974; Altamura et al. 1991; Della Rovere et al. 2013). The histological time course revealed that the cambial cells initiated the AR process in carob, and a similar number of primordia appeared at the same time in the cuttings independently of the AR-inductive treatment. However, the samples forming ARs increased up to culture end (fourth week) only in the presence of IBA + 5-BDPU. The histological analysis in pine microcuttings under the same treatments showed strong similarities, even if the founder cells of the ARs were the cells of the resin ducts and of the parenchyma external to them. In addition, 5-BDPU applied alone enhanced xylogenesis in both species, as alternative program to adventitious rooting.

\section{Materials and methods}

\section{Preparation of chemical solutions}

The 5-BDPU and the 6-BDPU were dissolved in dimethylsulfoxide (DMSO). The final concentration of DMSO in the in vitro culture medium did not exceed the one considered toxic $(0.2 \%$, v/v) (Schmitz and Skoog 1970). The 5-BDPU and the 6-BDPU, synthesized as previously reported (Ricci et al. 2006), were of analytical grade. The aqueous solutions of benzylaminopurine (BAP), IBA and Kin were sterilized by filtration using $0.2-\mu \mathrm{m}$ pore size sterile disposable filter units (Schleicher and Schuell).

\section{Plant material and in vitro culture conditions for carob}

In vitro shoot cultures of Ceratonia siliqua L., clone 34, were maintained as previously reported (Romano et al. 2002) with minor modifications as follows. The microcuttings, deprived of apices, were propagated in micropropagation (MP) medium [salts of Murashige and Skoog 1962 (MS), plus $2 \mathrm{mg} / \mathrm{l}$ glycine, $100 \mathrm{mg} / \mathrm{l}$ myo-inositol, $0.5 \mathrm{mg} / \mathrm{l}$ nicotinic acid, $0.5 \mathrm{mg} / \mathrm{l}$ pyridoxine $\mathrm{HCl}, 0.1 \mathrm{mg} / \mathrm{l}$ thiamine $\mathrm{HCl}, 30 \mathrm{~g} / \mathrm{l}$ sucrose, $0.8 \%$ (w/v) Phyto Agar (Duchefa), $5.8 \mathrm{pH}$ ], supplemented with $0.88 \mu \mathrm{M}$ BAP. After a 6-week incubation period in a growth chamber at $25 \pm 1{ }^{\circ} \mathrm{C}$ and light intensity of $20 \mu \mathrm{mol} \mathrm{m}{ }^{-2} \mathrm{~s}^{-1}$ under $16 \mathrm{~h}$ photoperiod (standard conditions from now on), clusters consisting of 3-4 shoots were formed by axillary branching. The newlyformed individual shoots $(1.5 \mathrm{~cm}$ in length, by average $)$ were used either for further micropropagation or for rooting induction experiments.

\section{Rooting of carob microcuttings}

To optimise the adventitious rooting protocol, stocks of about 50 carob microcuttings of the same length, randomly chosen within the micropropagated shoot-population, were cultured in the presence of the different compounds (i.e., IBA, 5-BDPU, 6-BDPU, Kin) alone or in combinations, at different concentrations, and for different induction periods as follows.

In a first set of experiments, the microcuttings were incubated in single tubes on the culture medium described above, supplemented with 0.1 and $1 \mu \mathrm{M}$ IBA, $10 \mu \mathrm{M}$ 5-BDPU, $10 \mu \mathrm{M}$ 6-BDPU, $0.1 \mu \mathrm{M}$ IBA plus $10 \mu \mathrm{M}$ 5-BDPU, $0.1 \mu \mathrm{M}$ IBA plus $10 \mu \mathrm{M}$ 6-BDPU, $1 \mu \mathrm{M}$ IBA plus $10 \mu \mathrm{M} 5$-BDPU, and $1 \mu \mathrm{M}$ IBA plus $10 \mu \mathrm{M}$ 6-BDPU. The tubes were maintained in the darkness for 7 days at $24 \pm 1{ }^{\circ} \mathrm{C}$, then the microcuttings were transferred in $\mathrm{HF}$ medium in a growth chamber, at the standard conditions, up to the end of the experiment (4 weeks).

In a second set of experiments, the microcuttings were incubated in single tubes on the culture medium described above supplemented with $1 \mu \mathrm{M}$ IBA, $10 \mu \mathrm{M}$ 5-BDPU, $10 \mu \mathrm{M}$ 6-BDPU, $1 \mu \mathrm{M}$ IBA plus $10 \mu \mathrm{M}$ 5-BDPU, and $1 \mu \mathrm{M}$ IBA plus $10 \mu \mathrm{M}$ 6-BDPU. The tubes were maintained in the darkness for 3 days at $24 \pm 1{ }^{\circ} \mathrm{C}$, then the microcuttings were transferred in $\mathrm{HF}$ medium in a growth chamber, at the standard conditions, up to the end of the experiment (4 weeks). 
In the third set of experiments, the microcuttings were incubated in single tubes on the culture medium described above supplemented with $1 \mu \mathrm{M}$ IBA, $10 \mathrm{nM}$ Kin, and $1 \mu \mathrm{M}$ IBA plus $10 \mathrm{nM}$ Kin. The tubes were maintained in the darkness for 3 days at $24 \pm 1{ }^{\circ} \mathrm{C}$, then the microcuttings were transferred in HF medium in a growth chamber, at the standard conditions, up to the end of the experiment (4 weeks).

For each set of experiments control was performed with microcuttings cultured in HF medium, containing DMSO, under the same culture conditions, and protruded ARs were scored after 4 weeks.

Results are shown as percentage of microscopic rooting response (i.e., number of microcuttings with AR-primordia on the total microcuttings per treatment) and mean density ( $\pm \mathrm{SE}$ ) of AR-primordia at day 12 (i.e., the mean number of AR-primordia per mm of basal cutting per treatment), and as percentage of macroscopic rooting response (i.e., number of microcuttings with emerged ARs on the total microcuttings per treatment) and mean number $( \pm S E)$ of ARs per rooted microcutting at culture end. The experiments were carried out using at least 10 microcuttings per treatment and repeated twice.

\section{Acclimatisation}

Acclimatisation of the in vitro-rooted carob plantlets was carried out in a growth chamber at a light intensity of $20 \mu \mathrm{mol} \mathrm{m}{ }^{-2} \mathrm{~s}^{-1}$ under fluorescent tubes with a $16 \mathrm{~h}$ photoperiod. Day/night temperatures were 25 and $21^{\circ} \mathrm{C}$, respectively. In vitro-rooted carob plantlets obtained by 3-day treatments with $1 \mu \mathrm{M}$ IBA and/or $1 \mu \mathrm{M}$ IBA plus 5or 6-BDPUs were gently washed-free of agar, then each plantlet was transferred to a vessel containing a $3: 1(\mathrm{v}: \mathrm{v})$ wet mixture of garden soil:perlite. This substrate had been autoclaved before use. The vessels were covered with a transparent plastic film during the first week of acclimatisation and this was gradually removed to promote hardening. After 20 days the plantlets were fully acclimatised and transferred to greenhouse conditions. Ten rooted plantlets obtained under each rooting treatment were used and the acclimatisation stage was repeated twice. The number of surviving plants was recorded after 4 weeks.

\section{Plant material and culture conditions for pine}

Pinus radiata D. Don hypocotyl cuttings from 21-day-old seedlings were obtained and cultured in the presence of aqueous solutions of $1 \mu \mathrm{M}$ IBA and/or $10 \mu \mathrm{M}$ 5-BDPU, or in distilled water containing DMSO (control treatment), as previously described (Brunoni et al. 2014).

\section{Histological analysis in carob and pine}

For histological analysis of adventitious root formation in the presence of IBA, 5-BDPU, and Kin, the basal 5-mmsegments of carob microcuttings treated with $1 \mu \mathrm{M}$ IBA, $10 \mu \mathrm{M} 5$-BDPU, $1 \mu \mathrm{M}$ IBA plus $10 \mu \mathrm{M}$ 5-BDPU, $10 \mathrm{nM}$ Kin, $1 \mu \mathrm{M}$ IBA plus $10 \mathrm{nM}$ Kin, and $\mathrm{HF}$ medium containing DMSO, as control, were fixed in formalin-acetic acid-alcohol (FAA), dehydrated in a tertiarybutyl-alcohol series, gradually embedded in paraffin, transversely sectioned at $10 \mu \mathrm{m}$ thickness with a rotary microtome ( $\mathrm{Re}$ ichert-Jung 2040) and stained with safranin-fast green (Berlyn and Miksche 1976). Carob cuttings were randomly sampled at the beginning of the rooting experiment (day 0 ), and at day 3, 6 and 12 for each treatment (10 cuttings per sampling day). The histological images were acquired in digital form with a Nikon digital camera (DMX 1200) applied to a Nikon Y-FL Eclipse E 600 light microscope.

Histological analysis in the basal 5-mm-segments of pine was performed accordingly to Brunoni et al. (2014) and ten randomly selected hypocotyl cuttings were sampled at day 0, 6, 10 and 13 for each treatment. The histological images were acquired with Leica DMD 108 digital micro-imaging device.

\section{Statistical analysis}

The differences among the percentages of rooted cuttings were arcsine-transformed and then examined with the $\chi^{2}$ test ( $p \leq 0.1$ ), and those between the mean AR numbers of pairs of treatments examined with the Student's $t$ test ( $p \leq 0.1$ ) (Brunoni et al. 2014).

\section{Results}

\section{Optimisation of carob adventitious rooting protocol}

A first set of experiments was carried out to identify the most efficient concentration of IBA applied either alone for 7 days or in combination with either 5-BDPU or 6-BDPU at $10 \mu \mathrm{M}$ (Brunoni et al. 2014). The response was scored after four weeks from the beginning of the experiment. The percentage of rooted cuttings and the mean number of roots per cutting under HF were very low ( Table 1A). The urea derivatives applied alone did not change significantly the HF response (Table 1A), showing that both had no rooting inductive ability per se. By contrast, IBA, applied at either 0.1 or $1 \mu \mathrm{M}$ (Brunoni et al. 2014) stimulated the process, without significant changes in the response induced by both concentrations, neither in the percentage of rooted cuttings 
nor in the mean number of roots per cutting (Table 1A). For this reason, and based on the results previously obtained using pine cuttings (Brunoni et al. 2014), $1 \mu \mathrm{M}$ IBA was used for further experiments. No significant difference between the treatments of IBA combined with either of the two urea derivatives was found (Table 1A).

To highlight possible differences in the response induced by the two urea derivatives, cuttings were exposed to the urea derivatives for three days in a second set of experiments. The macroscopic response was evaluated after four weeks. The rooting response under HF was absent (Fig. 1a) or occasional (Supplementary Fig. 1a; Table 1B), whereas the rooting response under IBA alone $(1 \mu \mathrm{M})$ highly increased (Table 1B; Fig. 1b). Each of the two urea derivatives did not cause any significant variation in comparison with the HF treatment (Table 1B), showing no rooting or an occasional response (Fig. 1c; Supplementary Fig. 1b). The treatment of IBA plus 5-BDPU significantly enhanced the percentage of rooted cuttings in comparison with IBA alone (Table 1B). However, the mean root number was not increased (Table 1B; Fig. 1b, d), and callus formation was reduced (even absent, sometimes). The ARs always protruded from the basal portion of the cutting.

Because the combined presence of IBA and cytokinin (Kin) enhances adventitious rooting of the explants from numerous species, such as tobacco and Arabidopsis TCLs (Altamura et al. 1991; Della Rovere et al. 2013), IBA was applied in combination with Kin $(10 \mathrm{nM})$ for 3 days. The percentage of rooted cuttings significantly decreased in the presence of IBA combined with Kin in comparison with IBA alone (Table 1C; Supplementary Fig. 1c), and was very low when Kin was applied alone, similar to the results obtained under HF condition (Table 1C). The histological analyses at day 12 confirmed the inability of the cutting cells to initiate the rooting process under Kin alone because the majority of the explants still showed the day 0 histological structure (Supplementary Fig. 2a and b). By contrast, the histological analyses showed that AR-primordia were present under IBA plus Kin (Supplementary Fig. 2c), with a mean number of primordia per $\mathrm{mm}$ of basal cutting of $5.8( \pm 0.9)$ not significantly different from that obtained in the presence of IBA alone $(6.0 \pm 0.8)$.

\section{Acclimatisation}

Carob cuttings that rooted after 3 days of $1 \mu \mathrm{M}$ IBA and $1 \mu \mathrm{M}$ IBA plus $10 \mu \mathrm{M} 5$-BDPU or $10 \mu \mathrm{M}$ 6-BDPU treatments were acclimatised to ex vitro greenhouse conditions and resulted in well-developed plants. The percentages of acclimatisation of cuttings rooted after $1 \mu \mathrm{M}$ IBA plus $10 \mu \mathrm{M} 5$-BDPU or $10 \mu \mathrm{M}$ 6-BDPU treatments were higher than that obtained after $1 \mu \mathrm{M}$ IBA treatment ( 80 or 100 vs $75 \%$, respectively).

\section{Histological roles of 5-BDPU in carob cuttings}

A random sampling of cuttings treated as shown in Table 2 was carried out periodically to compare the final macroscopic results with the events occurring histologically during the culture.

At day 3, no histological differences induced by the treatments were observed in the cuttings, because the structure was very similar to that observed at day 0 (Supplementary Fig. 3 and Supplementary Fig. 2a).

At day 6 , the cuttings under HF conditions, and those treated with 5-BDPU, exhibited some events of endocytogenic proliferation (Altamura et al. 1991) in the pith cells (Fig. 2a, b, arrows). By contrast, a multilayered cambium (Fig. 3a), and cell divisions within the phloem-parenchyma (Fig. 3a-c) and the cortical one (Fig. 3b, c) similarly occurred in the cuttings treated with IBA alone or IBA + 5-BDPU.

At day 12, endocytogenesis was evident also in the control cuttings, i.e., cuttings under HF treatment (Fig. 2c, arrows), and the cambial cells formed a limited callus with xylogenic elements (Fig. 2e, arrow). Very sporadic primordia, and xylogenic cells, were formed by the callus produced by the cambium (indirect origin, Fig. 2e, f, arrow). Sporadic primordia were also observed in the cuttings treated with 5-BDPU, however xylogenesis was more extensive than under HF, but similarly located (Fig. 2d, arrow). In addition, a conspicuous formation of secondary xylem (deuteroxylem) was observed in the presence of 5-BDPU alone (Fig. 2g). The quantification of the histological response showed that the percentage of cuttings with AR-primordia was similarly low in HF and 5-BDPU treatments, as well as the mean number of primordia per $\mathrm{mm}$ of basal cutting (Table 2). AR-primordia also appeared at day 12, and showed cambial origin, in the presence of IBA, alone or in mixtures (Fig. 3e-h; Supplementary Fig. 2c). Callus was formed in the cortical parenchyma in the presence of IBA and IBA + Kin (Fig. 3d; Supplementary Fig. 2d), and resulted into a macroscopic mass at the cutting base at culture end (Fig. 1b; Supplementary Fig. 1c). The percentage of rooted cuttings and the mean number of ARs at the cutting base were similar with IBA alone and IBA + 5-BDPU (Table 2). However, under the latter treatment the AR-primordia frequently showed a more advanced development, even if not always a direct origin from the cambium (Fig. 3e, g, in comparison). Interestingly, small groups of xylary cells/strands confining with the primordia (Fig. 3g, arrows), and xylogenic clumps unrelated to root formation (Fig. 3h), also occurred. 
Table 1 Adventitious rooting of Ceratonia siliqua (carob) cuttings after 4 weeks of culture: (A) Effect of $10 \mu \mathrm{M} 5$-BDPU or $10 \mu \mathrm{M}$ 6-BDPU supplemented for 7 days alone or in the simultaneous presence of different concentrations of IBA; (B) effect of $10 \mu \mathrm{M}$
5-BDPU or $10 \mu \mathrm{M}$ 6-BDPU supplemented for 3 days, alone or in the simultaneous presence of $1 \mu \mathrm{M}$ IBA; (C) effect of $1 \mathrm{nM}$ Kin supplemented for 3 days, alone or in the simultaneous presence of $1 \mu \mathrm{M}$ IBA

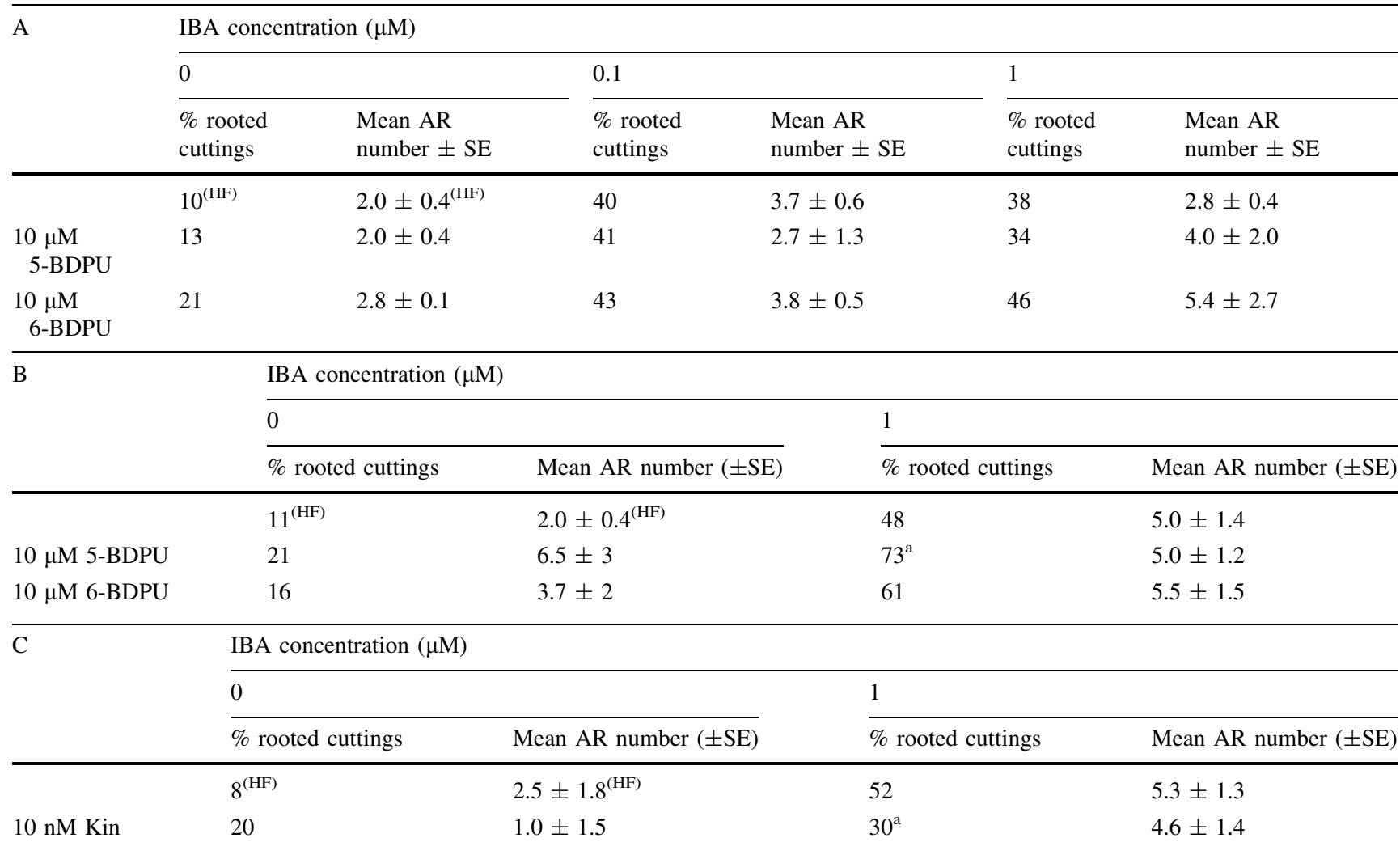

(HF) refers to the control treatment performed with microcuttings cultured in HF medium, containing DMSO. Results are expressed either as percentage of rooted cuttings or mean AR number per rooted cutting. For each treatment 10-15 cuttings were used and the experiments were repeated twice

${ }^{a}$ Significantly different at $p \leq 0.1$. Percentages/mean values followed by no asterisk are not significantly different $\left(\chi^{2}\right.$ test, $p \leq 0.1$ and Student's $t$ test, $p \leq 0.1$, respectively)

\section{Xylogenesis is induced by 5-BDPU in pine cuttings}

At day 0 the cuttings showed either ducts with meristematic initial cells and no lumen formation (Supplementary Fig. 4a, arrow), or well-developed ducts with a wide lumen surrounded by epithelial cells. The latter cells, however, showed large nuclei, as the meristematic cells, and random periclinal divisions (Supplementary Fig. 4b, arrow). In all cases the ducts were located externally to the primary xylem poles.

The histological analysis showed that there was no significant structural change induced by wounding at day 6 in the control cuttings (HF treatment), confirming previous results (Brunoni et al. 2014). At day 10, the initial cells of the resin duct either completed the regular differentiation of the resin duct (Fig. 4a, b, d, arrows) or proliferated into a meristematic clump without any lumen formation (Fig. 4a, $\mathrm{c}$, arrowheads). Interestingly, in both cases the parenchymatic cells surrounding these structures developed into short tracheids [Fig. 4b, c (arrow), d]. These tracheids became in conjunction with the forming deuteroxylem (Fig. 4a, d). In some cases the meristematic clumps differentiated a nest of tracheids in the centre, becoming xylogenic nodules (Fig. 4e). At day 13, nodules with xylogenesis increased (Supplementary Fig. 4c, d). When these nodules were prevalent, no correct cambial activity was observed (Supplementary Fig. 4c). By contrast, when at least some resin ducts were differentiated, the vascular cambium extended also externally to them and continued to produce deuteroxylem (Supplementary Fig. 4e, arrows).

No significant structural change occurred at day 6 in cuttings treated with 5-BDPU similarly to HF condition. At days 10 and 13 , the events continued to be similar to those of the HF treatment, with meristematic clumps observed at the position of resin ducts, and some of them being already developed into xylogenic nodules (Fig. 4f, g). The vascular cambium, which also extended externally to the resin ducts (Fig. 4h), was engaged into a lot of deuteroxylem 

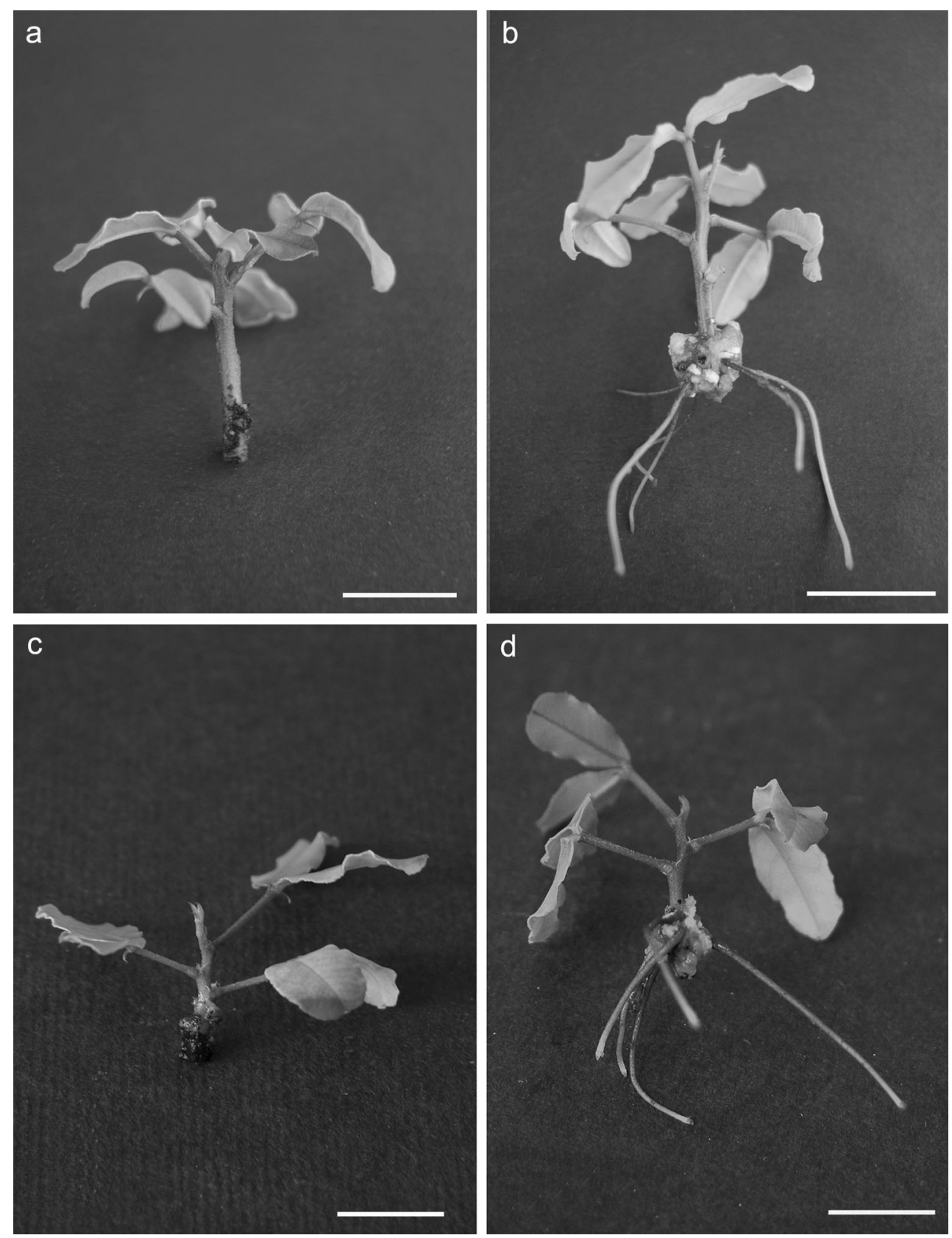

Fig. 1 Representative phenotypes of carob microcuttings obtained under different treatments: hormone free (HF) as control (a), $1 \mu \mathrm{M}$ IBA (b), $10 \mu \mathrm{M}$ 5-BDPU (c), $1 \mu \mathrm{M}$ IBA plus $10 \mu \mathrm{M}$ 5-BDPU (d). The treatments lasted 3 days in the darkness at $24 \pm 1{ }^{\circ} \mathrm{C}$, then the

cuttings were transferred to $\mathrm{HF}$ medium and cultured at $24 \pm 1{ }^{\circ} \mathrm{C}$, $20 \mu \mathrm{mol} \mathrm{m} \mathrm{m}^{-2} \mathrm{~s}^{-1}$ light intensity under $16 \mathrm{~h}$ photoperiod. Pictures were taken after 4 weeks of culture. Scale bars $1 \mathrm{~cm}$

formation (Fig. 4i) which enclosed the differentiated resin ducts, the meristematic clumps positioned as the resin ducts (Fig. 4h) and those that had become totally xylary (Fig. 4i, arrow). Both xylogenesis (Supplementary Fig. 4f-h) and deuteroxylem formation (Supplementary Fig. 4i) increased at day 13. At this day, no AR-primordium was observed in the controls and the cuttings treated with 5-BDPU.

\section{5-BDPU enhances rhizogenesis, but not xylogenesis, when combined with IBA in pine cuttings}

After 6 days of culture, the presence of IBA alone in the medium precocized the vascular cambium formation and activity in the most of the cuttings (Fig. 5a). This activity resulted into some deuteroxylem formation (Fig. 5b) but 
Table 2 Percentage of carob rooting explants per treatment at day 12 after histological analysis, and mean density, expressed as mean number of AR primordia per $\mathrm{mm}$ of basal portion of the cutting

\begin{tabular}{lll}
\hline Treatment & Percentage of microscopic rooting explants & Mean density of AR primordia per explant $( \pm$ SE $)$ \\
\hline HF & 30 & $1.0 \pm 0.2$ \\
$10 \mu \mathrm{M} \mathrm{5-BDPU}$ & 30 & $1.4 \pm 0.6$ \\
$1 \mu \mathrm{M} \mathrm{IBA}$ & $50^{\mathrm{a}}$ & $6.4 \pm 1.0^{\mathrm{a}}$ \\
$1 \mu \mathrm{M} \mathrm{IBA}+10 \mu \mathrm{M} \mathrm{5-BDPU}$ & $50^{\mathrm{a}}$ & $6.5 \pm 1.0^{\mathrm{a}}$ \\
\hline
\end{tabular}

Effect of $10 \mu \mathrm{M} 5$-BDPU or $1 \mu \mathrm{M}$ IBA supplemented for 3 days, alone or in the simultaneous presence. HF refers to the control treatment performed with microcuttings cultured in HF medium, containing DMSO. For each treatment 10 cuttings were used and the experiments were repeated twice

${ }^{\text {a }}$ Significantly different at $p<0.1$ with HF and 5-BDPU. Percentages/mean values followed by no letter/the same letter are not significantly different ( $\chi^{2}$ test, $p \leq 0.1$ and Student's $t$ test, $p \leq 0.1$, respectively)

mainly into meristematic clumps/areas (Fig. 5a, arrow). Interestingly, repeated cell divisions leading to periclinal derivatives also occurred by cells bordering the resin ducts, the same as tracheary element differentiation (Fig. 5b, arrow and arrowhead). This activity was also shown in the few cuttings not yet showing vascular cambium activity (Fig. 5c, d, arrows). Random divisions also occurred in the cortical parenchyma, possibly leading to callus formation.

As a consequence of both IBA and 5-BDPU application, the cuttings showed more meristematic clumps (Fig. 5e, f), but reduced cambial formation/activity, resulting into poor deuteroxylem production (Fig. $5 \mathrm{~g}$ ). Specific cells bordering the resin ducts were engaged into periclinal derivatives formation (Fig. 5h, arrow), similarly to the results obtained in cuttings treated with IBA alone, and equally cells near the resin ducts differentiated into tracheary elements (Fig. 5g, h, arrowheads).

After ten days of culture in the presence of IBA alone, the majority of cuttings continued to show vascular cambium activity with some deuteroxylem formation (Fig. 6a, b), and meristematic clumps of both cambial and resin-duct-cell origin (Fig. 6a, b, arrows) leading to rare AR-primordia formation (Fig. 6b). Meristemoids (Fig. 6d), young AR primordia (Fig. 6c, e), and xylogenic nodules (Fig. 6f), all located externally to the protoxylem, were more frequent in the cuttings in which the vascular cambium was not yet developed. As a consequence of both IBA and 5-BDPU application, the vascular cambium activity became visible in more cuttings than at the previous sampling (Fig. 5e, g), leading, in particular, to some deuteroxylem formation, sometimes including the resin ducts (Fig. $6 \mathrm{~g}$ ). In the other cuttings a high number of meristemoids, each confining with the protoxylem (Fig. 6h), became evident. Rare xylogenesis appeared in the meristematic zones (Fig. 6i, arrow), but some meristemoids already developed into AR-primordia (Fig. 6j).

After 13 days of culture, the cuttings treated with IBA alone either showed advanced secondary vascular development due to the continued activity of the vascular cambium (Supplementary Fig. 5a) or still showed no cambial activity, but extended formation of meristematic clumps (Supplementary Fig. 5b) and meristemoids (Supplementary Fig. 5c). Also AR-primordia were formed in the latter type of cuttings, and showed a well domed structure (Supplementary Fig. 5d). As a consequence of IBA + 5-BDPU application, ARs were widely present (Supplementary Fig. 5e), and showed advanced development with the differentiation of the procambium in conjunction with the resin duct at its base (Supplementary Fig. 5f).

\section{Discussion}

Adventitious root formation is often a limiting step for in planta and in vitro vegetative plant propagation programmes, as a lot of species, mainly woody plants, are recalcitrant to form ARs. Auxin has been recognized as the major factor in controlling and stimulating AR formation. However, the endogenous bulk of the most important auxin in plants, IAA, is not always adequate to induce ARs. Therefore, an exogenous supplementation is often necessary, even if the increased amount of auxin thus available (endogenous plus exogenous auxin) could reach a detrimental supra-optimal level, causing formation of a high amount of basal callus from which stunted and/or malformed ARs might protrude. The frequent lack of a good vascular connection between these ARs and the cutting vasculature has been recognised as the main problem of their malfunctioning, with negative consequences for cutting survival (Fleck et al. 2009). The simultaneous presence of unusual chemicals, e.g., 5-BDPU or 6-BDPU, plus auxin, has been described to promote adventitious rooting, reducing the disadvantages of a treatment with auxin alone (Ricci et al. 2006; Brunoni et al. 2014). To enlarge the 

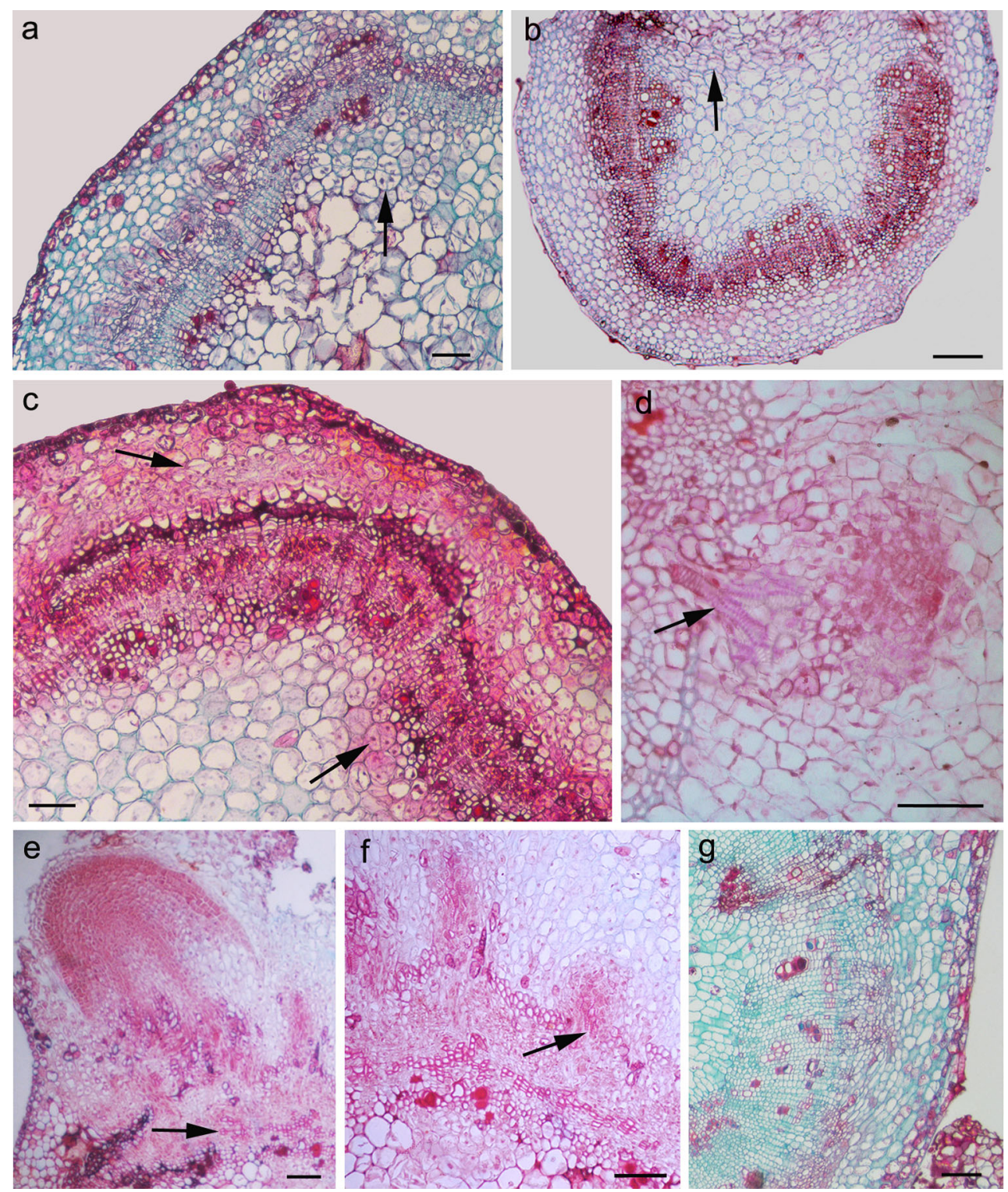

Fig. 2 Histological images of carob microcuttings (stem base transections) at day $6(\mathbf{a}, \mathbf{b})$ and day $12(\mathbf{c}-\mathbf{g})$ under control (HF) $(\mathbf{a}, \mathbf{c}, \mathbf{e}, \mathbf{f})$ and $10 \mu \mathrm{M}$ 5-BDPU (b, d, g) treatments. The 5-BDPU treatment lasted 3 days, then the cuttings were transferred to $\mathrm{HF}$ medium. a, b Stem structure as at culture onset, but with endocytogenic proliferation in the pith cells (arrows). c Endocytogenesis events in the pith and cortical parenchyma (arrows) at higher magnification. d Very young AR primordium formed in the presence

action spectrum of these urea derivatives to commercial and/or environmental important species, but also to extend the knowledge on their morphogenic roles, they were presently used in in vitro micropropagated cuttings of Ceratonia siliqua L. Indole-3-butyric acid, i.e., the endogenous precursor of IAA (Liu et al. 2012, and references therein), is useful in many culture systems to improve AR formation when applied exogenously, alone of 5-BDPU with de novo formed xylary cells (arrow) at the junction with cambium. e AR primordium of indirect origin, i.e. arising from callus formed by the cambium. Xylogenic elements of indirect cambial origin are also shown (arrow). f AR primordia of indirect origin and xylogenic elements at their base (arrow). g Pronounced deuteroxylem production by the cambium. Scale bars $50 \mu \mathrm{m}(\mathbf{d}-\mathbf{f})$, $100 \mu \mathrm{m}(\mathbf{a}-\mathbf{c}, \mathbf{g})$

or in combination of a little amount of cytokinin. By the use of this hormone, present results showed that the simultaneous supplementation of IBA with 5-BDPU enhanced carob adventitious rooting. By contrast, the histological analysis showed that, when applied in the absence of IBA, this urea derivative enhanced xylogenesis, and the result was confirmed in Pinus radiata D. Don cuttings. 

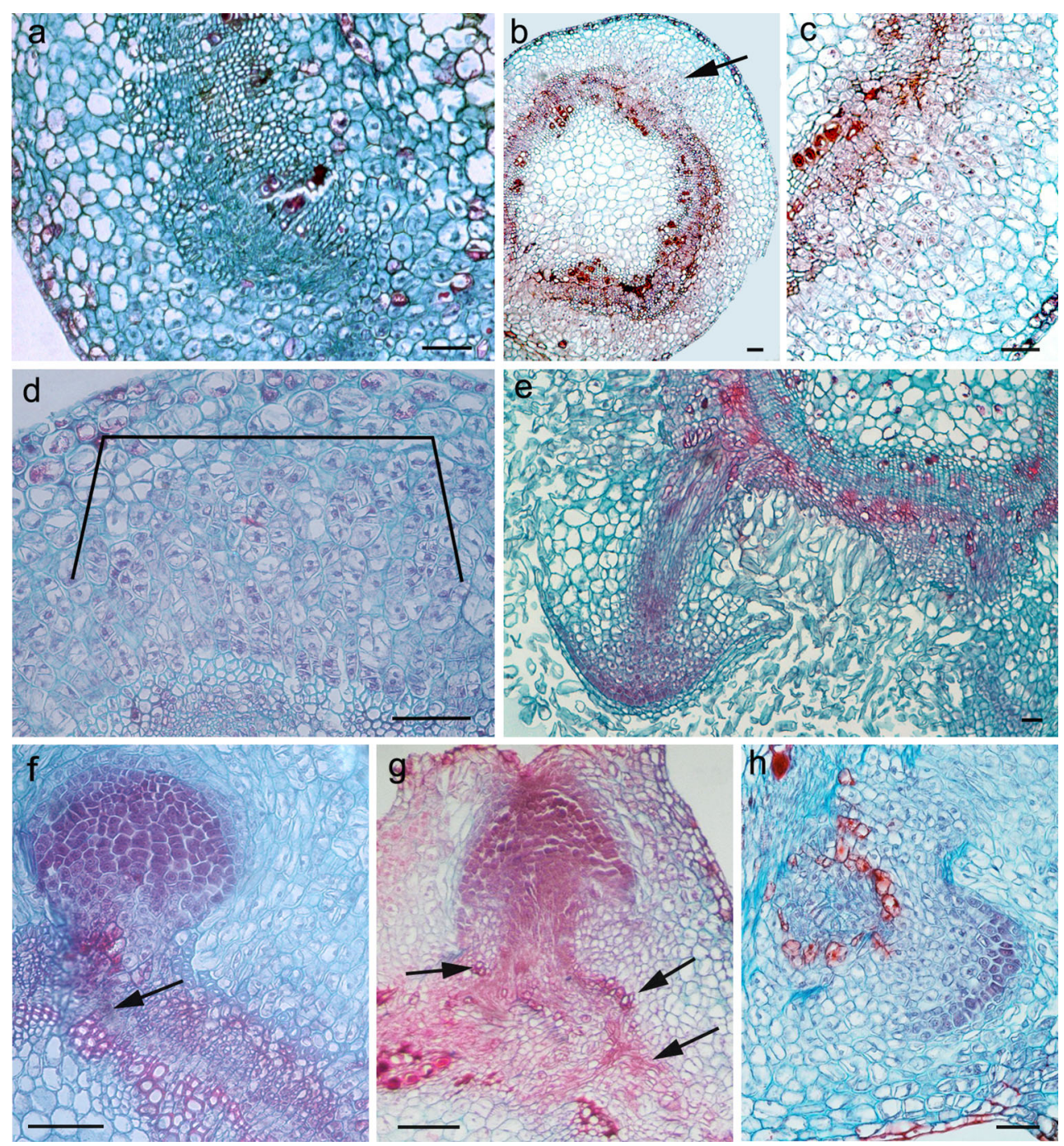

Fig. 3 Histological images of carob microcuttings (stem base transections) at day $6(\mathbf{a}-\mathbf{c})$ and day $12(\mathbf{d}-\mathbf{h})$ under $1 \mu \mathrm{M}$ IBA $(\mathbf{a}$, d, f) and $1 \mu \mathrm{M}$ IBA plus $10 \mu \mathrm{M}$ 5-BDPU (b, c, e, g, h) treatments. The hormonal treatments lasted 3 days, then the cuttings were transferred to HF medium. a Multilayered cambium between secondary phloem and xylem, and cell divisions in the phloem. bc Cell divisions within the phloem and cortical parenchyma (arrow), magnified in c. d Callus formation in the cortical parenchyma

\section{5-BDPU is able to enhance IBA-induced AR formation in carob cuttings}

To verify the effectiveness of either 5-BDPU or 6-BDPU in enhancing adventitious root formation, both were firstly supplemented alone or in combination with different concentrations of exogenous IBA $(0.1$ and $1 \mu \mathrm{M})$ to in vitro micropropagated cuttings of carob at a single concentration $(10 \mu \mathrm{M})$, for 1 week in darkness, and then transferred to the light under HF conditions. No enhancement of AR formation was obtained. As a consequence, the rooting induction period was reduced to 3 days, the highest IBA (marked area). e Advanced-in-development AR primordium of direct cambial origin. f AR primordium of direct cambial origin. The cambial cells at its base are shown by the arrow. g Advanced-indevelopment AR primordium of indirect origin. The arrows indicate xylary cells and strands confining with the primordium. h Xylogenic clump near an AR primordium. Scale bars $50 \mu \mathrm{m}(\mathbf{a}-\mathbf{f}), 100 \mu \mathrm{m}(\mathbf{g})$, $200 \mu \mathrm{m}(\mathbf{h})$

concentration was applied, followed by a transfer onto HF medium, in accordance with a well-known rooting procedure (George 1993) and the different hormonal requirements of the successive phases of AR formation. In fact, during the first $24 \mathrm{~h}$ specific cells in a stem cutting, usually situated near the vascular system, become competent to respond to auxin (dedifferentiation phase), with an high auxin level useful to enhance their number. Then, up to $96 \mathrm{~h}$, the competent cells divide forming meristemoids (induction phase), and finally meristemoids develop into dome-shaped primordia (differentiation phase), further developing into ARs. In this latter phase, exogenous auxin 

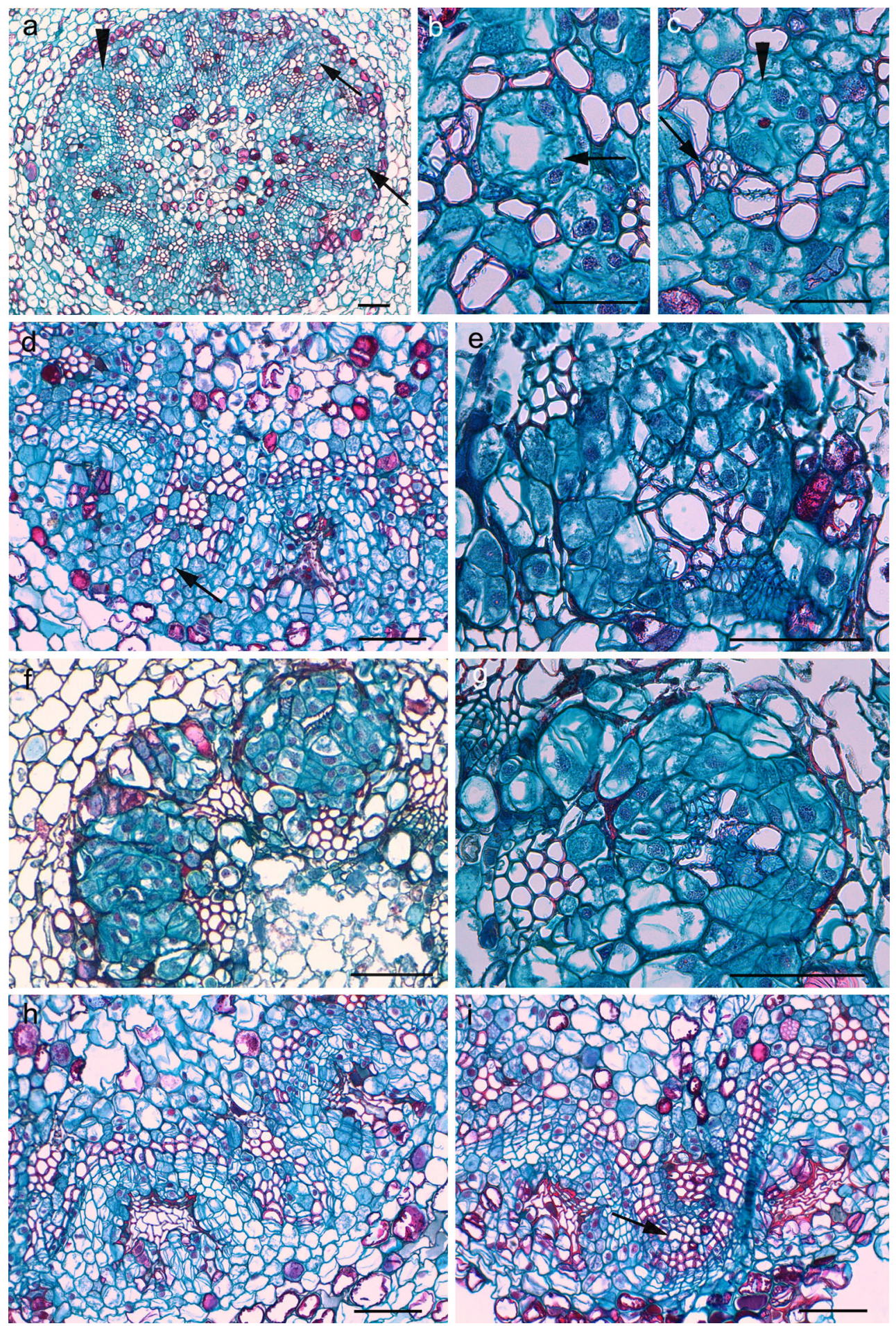

Fig. 4 Histological images of pine hypocotyl cuttings (basal transections from 21-day-old seedlings) at day 10 of culture, under control (HF) (a-e) and $10 \mu \mathrm{M}$ 5-BDPU (f-i) treatments [details of culture conditions in Brunoni et al. (2014)]. a Presence of the resin ducts within the vascular system. Ducts with a formed lumen (arrows) and meristematic ducts without the lumen (arrowhead) are shown. b Magnification of a completely differentiated resin duct (arrow), with tracheary elements around the central lumen. c Meristematic clump (arrowhead) formed by the proliferation of the initial cells of a resin duct partially surrounded by short tracheids (arrow). d Detail of the vascular system showing the vascular cambium producing deuteroxylem joined with the tracheids around the resin ducts (arrow). e Xylogenic nodule. f Meristematic nodules, at the position of the resin ducts, with few xylary elements inside. $\mathrm{g}$ Xylogenic nodule in a 5-BDPU-treated cutting. $\mathbf{h}$ Detail of the vascular system showing vascular cambium also extending externally to meristematic clumps and resin ducts. i Conspicuous production of deuteroxylem by the cambium including a xylary nodule positioned as a resin duct (arrow). Scale bars $50 \mu \mathrm{m}(\mathbf{b}, \mathbf{c}), 100 \mu \mathrm{m}(\mathbf{a}, \mathbf{d}-\mathbf{i})$ 

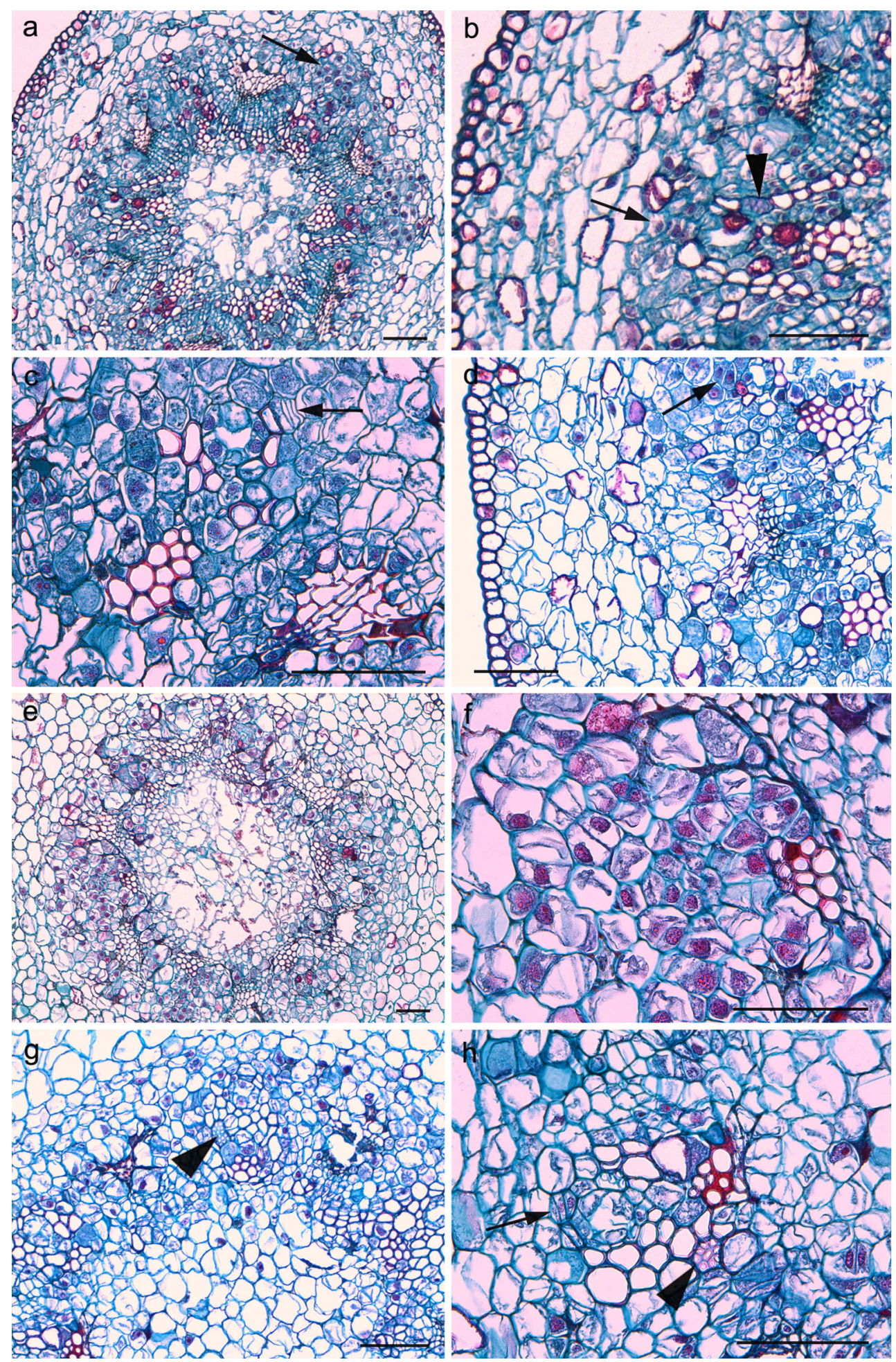

Fig. 5 Histological images of pine hypocotyl cuttings (basal transections from 21-day-old seedlings) at day 6 of culture under $1 \mu \mathrm{M}$ IBA (a-d) and $1 \mu \mathrm{M}$ IBA plus $10 \mu \mathrm{M}$ 5-BDPU (e-h) treatments. a Section showing the activity of the vascular cambium producing some deuteroxylem and the presence of meristematic clumps (arrow). b-d Periclinal division activity by some cells bordering the resin ducts (arrows), and tracheary element formation (arrowhead in b). e- f Formation of numerous meristematic clumps around the vascular system, one of which magnified in $\mathbf{f}$. $\mathbf{g}$ Poor deuteroxylem production by the vascular cambium, and tracheary elements of non-cambial origin differentiated near a resin duct (arrowhead). h Formation of periclinal derivatives (arrow) by the division of cells bordering a resin duct, and presence of tracheary elements (arrowhead). Scale bars $100 \mu \mathrm{m}$ 

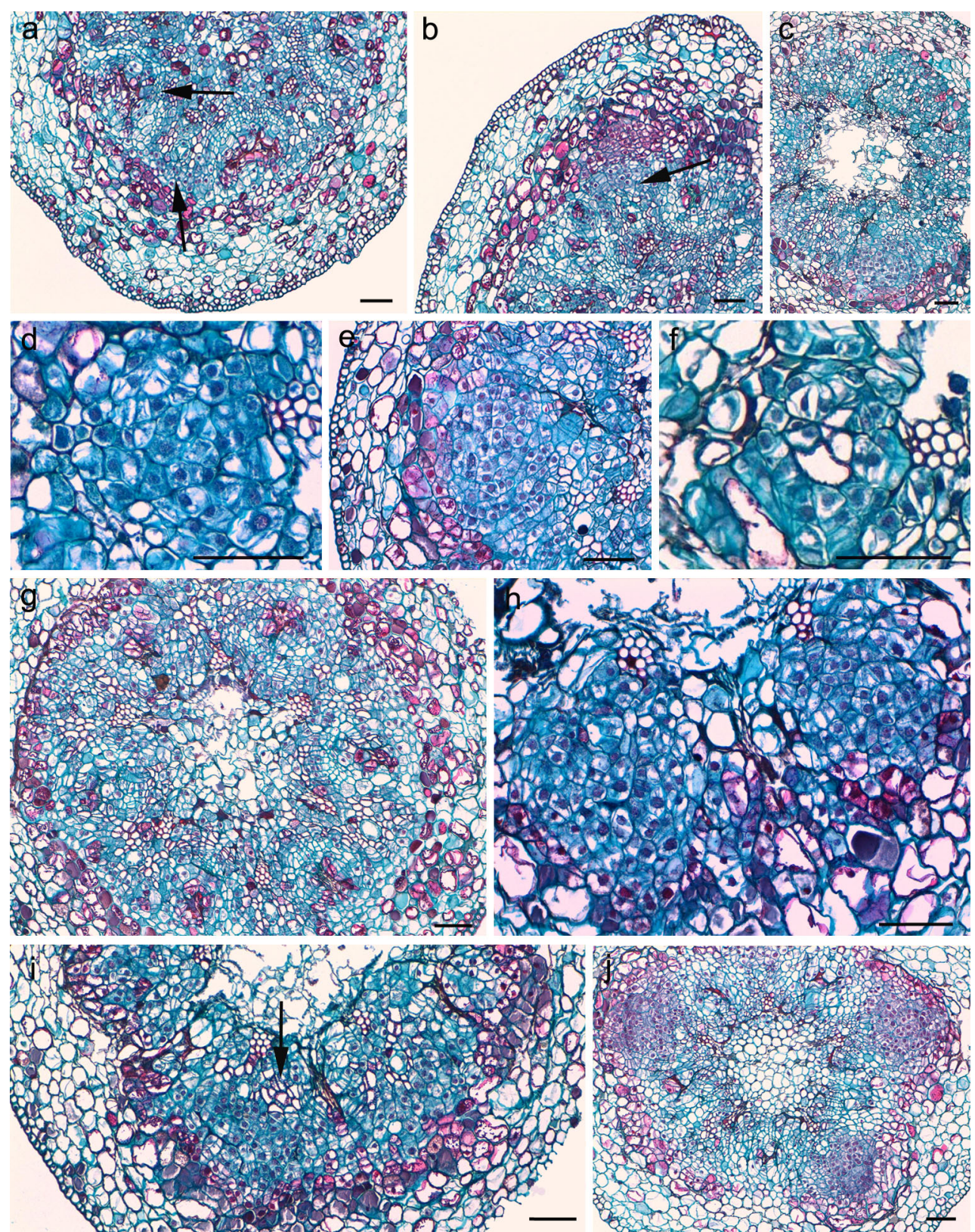

Fig. 6 Histological images of pine hypocotyl cuttings (basal transections from 21-day-old seedlings) at day 10 of culture under $1 \mu \mathrm{M}$ IBA $(\mathbf{a}-\mathbf{f})$ and $1 \mu \mathrm{M}$ IBA plus $10 \mu \mathrm{M}$ 5-BDPU (g-j). a Some deuteroxylem formation and meristematic clumps of cambial and resin-duct-cell origin (arrows). b Young AR primordium originated by the division of resin duct cell-derivatives (arrow). c Cutting with no development of the vascular cambium, but with meristemoids and

is not required, rather its presence could be detrimental (De Klerk et al. 1999; De Klerk 2002).

By the second set of experiments, BDPUs continued to be ineffective when supplemented alone to the carob cuttings, with macroscopic ARs being merely sporadic as in the HF treatment, in accordance to the known root recalcitrance of carob, and the inability of these urea derivatives young AR primordia. d-e Meristemoid (d) and young AR primordium (e) at high magnification. $\mathbf{f}$ Xylogenic nodule. $\mathbf{g}$ Detail of the vascular system with the activity of the vascular cambium forming deuteroxylem, which includes the resin ducts. h Two meristemoids, each confining with a protoxylem cell group. i Wide meristematic zones with poor xylogenesis inside. $\mathbf{j}$ Three AR primordia formed externally to the resin ducts. Scale bars $100 \mu \mathrm{m}$

to cause per se AR formation in other difficult-to-root culture systems, e.g. pine hypocotyl cuttings (Brunoni et al. 2014). On the contrary, when 5-BDPU, in particular, was supplemented in the simultaneous presence of exogenous IBA, AR formation was significantly enhanced in comparison with the results obtained in the presence of IBA alone. This result demonstrates that the urea derivative 
exerts a promoting effect in adventitious rooting of carob in the presence of an IBA concentration ten-fold lower than the one used in other research works with the same species (Sebastian and McComb 1986; Romano et al. 2002). Moreover, it confirms the AR-adjuvant activity of this urea derivative when supplemented with exogenous auxin (Ricci et al. 2006; Brunoni et al. 2014).

This is the first time that the proven rooting effectiveness of 5-BDPU is compared with that of kinetin, a synthetic cytokinin-like compound. Even if cytokinins have been generally considered as inhibitors of adventitious rooting, several studies have demonstrated that small amounts of exogenous cytokinin, in the presence of exogenous auxin, may be required for a good AR formation in vitro (Tran Thanh Van et al. 1974; Van Staden and Harty 1988; Altamura et al. 1991; De Klerk et al. 2001; Della Rovere et al. 2013). By contrast, when supplemented to carob cuttings, the mixture made by IBA plus Kin was ineffective, as the percentage of rooted cuttings was significantly reduced in comparison with that obtained with the IBA alone treatment. Taken together, 5-BDPU and Kin seem to act in a counteracting way in the carob AR-programme, with 5-BDPU enhancing, and Kin inhibiting, the pivotal inductive role of IBA on the process.

The presence of 5-BDPU seemed to facilitate auxin (i.e. exogenous IBA) activity, improving the ability of competent cells to respond to the auxin stimulus, causing a higher $\mathrm{AR}$ induction and a correct AR development than in the presence of auxin alone. In fact, the disordered cell divisions that often characterize the first culture phase in response to auxin supplementation, and that lead to the formation of a high amount of undifferentiated cells, i.e. a callus mass, was considerably reduced under 5-BDPU plus IBA. This result itself is a valuable one, as the way to obtain well-rooted plants is to keep callus growth to a minimum, thus favouring plant survival during the ex vitro acclimatisation phase, as, in fact observed. It follows that BDPUs, albeit synthetic compounds, do not exert any deleterious effect on all the stages of the in vitro micropropagation programme of carob, and their application may be suggested on a large scale.

\section{Xylogenesis is a competitive program to rhizogenesis in carob and pine cuttings}

Both in planta and in in vitro cultured explants/single cells, xylogenesis is an auxin-alone- or an auxin-plus-cytokininmediated programme (Fukuda 1997; McCann et al. 2000). In accordance, structural and anatomical similarities have been found between the xylem produced in planta and xylogenesis in vitro, e.g., between the xylem cells of the hypocotyl of Zinnia elegans in planta, and the tracheary elements produced in vitro by the trans-differentiation of the mesophyll cells (Pesquet et al. 2003). Moreover, genes in common between the processes in planta and in vitro have been found (Miyashima et al. 2013), e.g. the $S H R$ and $S C R$ transcription factors (TFs) of the GRAS family, the $H D-Z I P$ III ATHB8, and the auxin-influx carrier $A U X 1$ (Baima et al. 2014; Della Rovere et al. 2015). The xylary elements de novo formed in vitro are usually tracheids characterized by secondary cell walls with annular, spiral or pitted thickenings, the latter ones with numerous and wide pits, also in the case of conifers (Grönroos and von Arnold 1985, and present results). Moreover, both in planta and in vitro, the initiation of xylary cells needs an endogenous accumulation of auxin in the founder cells, e.g., of the hypocotyl pericycle, stem endodermis, callus, procambium, vascular cambium (Baima et al. 1995, 2000, 2001; Della Rovere et al. 2013, 2015; Abarca et al. 2014). In in vitro systems, endogenous auxin accumulation occurs independently of the fact that xylogenesis needs a preceding cell proliferation phase or results from a trans-differentiation event (Sundberg et al. 2000; McCann et al. 2000). Moreover, in Arabidopsis TCLs, xylogenesis occurs as xylary nodules and strands in addition to, and in competition with, AR formation (Falasca et al. 2004; Della Rovere et al. 2015), but the same occurs in other culture systems, e.g., the IBA-cultured tobacco, Prunus avium and walnut microcuttings (Biondi et al. 1994; Falasca et al. 2000; Faivre-Rampant et al. 2003).

In Arabidopsis it has been recently demonstrated that the fine-tuning control between AR formation and xylogenesis involves SHR, SCR and AUX1, but the involvement of ATHB8, or other members of the HD-ZIP III TF family, has been also hypothesized (Della Rovere et al. 2015). In fact, specific HD-ZIP III TFs are regulated by the microRNA165/6 produced by the SHR-SCR-complex (Carlsbecker et al. 2010). The SHR-SCR-complex activates numerous downstream genes, including genes necessary for AR construction, but also degrades the mRNAs of specific HD-ZIP III TFs by the microRNA165/6 activity, favouring AR formation through an inhibition of xylary development (Della Rovere et al. 2015, and references therein). Present results sustain that adventitious rooting and xylogenesis are antagonistic events also in the microcuttings of carob, with both processes occurring in the same cell type (i.e. the cambial cells). Interestingly xylogenesis occurs in carob as deuteroxylem and xylary nodule formation. Also in pine the non-realization of the AR program may be inversely linked with the enhancement of the xylary program, independently of the causative factor, i.e., advanced age of the cutting (Abarca et al. 2014) or culture in the absence of the root-inductive exogenous auxin input (present results). Moreover, in pine, differences in endogenous IAA accumulation, and in its vascular cell localization, have been reported for the young (21-days- 
old), rooting-competent, hypocotyl cuttings, in comparison with the old (90-days-old), non-rooting, but xylary competent, ones, and were enhanced by the inhibition of auxin transport (Abarca et al. 2014).

\section{5-BDPU enhances xylogenesis in the absence of exogenous IBA, and affects the switching to rhizogenesis in the presence of exogenous IBA}

In seedlings and TCLs of Arabidopsis, xylogenesis and AR formation are both triggered by an endogenous IAA accumulation, with differences between the initiation of either program related to the activity of the auxin cellular influx carrier AUX1, and the SCR-SHR-complex (Della Rovere et al. 2015). AtSCR is an auxin-induced gene (Moubayidin et al. 2013) and it is activated by AtSHR (Helariutta et al. 2000). Also AtATHB8 is auxin-induced, and its activation identifies the pre(pro)cambial cell state (Baima et al. 2014, and references therein).

In cultured chestnut shoots the expression of a $S C R$ LIKE (SCL) gene, i.e., CsSCL1, is induced by the IBA treatment before AR formation, i.e., at the onset of cell divisions, which are restricted to the cambial zone and derivative cells (Vielba et al. 2011). A similar expression pattern has been shown by a PrSCL1 gene in 21-days-old pine hypocotyls cultured under the same IBA-treatment presently adopted, in which a $\operatorname{PrSHR}$ gene is also early activated in the same cambial region, but independently of the exogenous auxin input (Sánchez et al. 2007; Solé et al. 2008). Present results show that exogenous IBA, when applied without 5-BDPU, is capable of enhancing AR formation but also of inducing xylogenesis, however, also the application of 5-BDPU without IBA induces xylogenesis. Interestingly, when applied together, AR formation is enhanced and xylogenesis highly reduced. Therefore, xylogenesis might need lower levels/transport of auxin than AR formation in pine and carob. The results show that the urea derivative acts as adjuvant of auxin in both processes, favouring xylogenesis when acts as an enhancer of the endogenous auxin only, and rhizogenesis when acts as an enhancer of exogenous IBA.

The IAA influx carrier AUX1 is known to affect the switching between in vitro organogenic programs in Arabidopsis (Kakani et al. 2009), as well as the switching between xylogenesis and AR formation in seedlings and TCLs (Della Rovere et al. 2015). In this plant and culture system, the gene expression occurs in both AR initiating cells and xylogenesis initiating cells, and is independent of exogenous IBA (Liu et al. 2012; Della Rovere et al. 2015). There is no information about a possible enhancing effect of 5-BDPU, and other similar urea derivatives, on the expression/activity of this auxin influx carrier. However, based on previous and present results, it could be possible that 5-BDPU positively affects the cell influx of endogenous auxin by this carrier, causing in the target cells, i.e., the cambial cells of carob cuttings, and the cambial cells and resin duct epithelial cells of pine cuttings, the obtaining of an auxin level sufficient for the beginning of the xylogenic program. This precocious canalization of the target cells might result into the expression of the auxin-induced genes responsible for xylary initiation, e.g., HD ZIP III TFs, including $A T H B-8$, as sustained by our recent results about AUX1 and ATHB-8 relationship in the xylogenesis from Arabidopsis TCLs (Altamura et al., unpublished).

Present results also show that 5-BDPU enhances AR formation, but not xylogenesis, when combined with exogenous IBA. Following our hypothesis that the induction of AR formation needs more auxin than xylogenesis, and that 5-BDPU is an adjuvant of auxin action, able to magnify the response to auxin, endogenous and/or exogenously applied one (Brunoni et al. 2014), it remains to more deeply investigate which could be the target genes involved in the process. Possible candidates are SCR-LIKE and SHR-LIKE genes, whose expression has been already described in different AR-inductive conditions in 21-daysold pine microcuttings (Sánchez et al. 2007; Ricci et al. 2008; Solé et al. 2008; Brunoni et al. 2014). Even if genes affecting AR response in carob have been not yet identified, we cannot exclude that in IBA-treated cuttings of carob in the simultaneous presence of 5-BDPU the expression of SCR-LIKE gene(s) could be enhanced, as already demonstrated in pine (Brunoni et al. 2014). This could affect the SHR-LIKE signalling, as occurs in Arabidopsis (Koizumi et al. 2012), increasing the SCR-SHR activity necessary for the induction of the downstream ARspecific genes, as already demonstrated in the IBA + Kincultured TCLs (Della Rovere et al. 2015). If this could be the situation, the increased SCR-SHR activity might also result into enhanced miRNA165/6 activity causing higher degradation of the mRNAs of the TFs upstream to xylary genes (Carlsbecker et al. 2010), thus negatively affecting xylogenesis.

In conclusion, present results highlight new roles for an urea derivative up to now known to increase AR formation in combination with exogenous/endogenous auxins in various culture systems and species, i.e. a function in the induction of xylogenesis, and in the switching from xylogenesis to rhizogenesis.

Acknowledgments The authors would like to thank Prof. R. Perris, University of Parma, for the use of microscopy facilities. This research was supported by Local Funding for Research (FIL funds), University of Parma, to AR, and partially by the Spanish Ministry of Economy and Competitiveness (AGL2011-30462) to CDS, and by Sapienza University of Rome (C26H157ANK) to MMA. 
Author contribution $A R$ planned the research, carried out the experiments with carob, the pine culture for histology, and contributed to the discussion. $E R$ and $F B$ carried out the experiments with carob and the following acclimatisation. $L D$ and $E S$ carried out the histological fixation and staining, and the carob micropropagation, respectively. $L F$ carried out the histological analyses and their quantification, and contributed to the discussion. $B R$ and $C D S$ contributed to the discussion. MMA interpreted and discussed the histological results.

\section{Compliance with ethical standards}

Conflict of interest The authors declare that they have no conflict of interest.

Open Access This article is distributed under the terms of the Creative Commons Attribution 4.0 International License (http://crea tivecommons.org/licenses/by/4.0/), which permits unrestricted use, distribution, and reproduction in any medium, provided you give appropriate credit to the original author(s) and the source, provide a link to the Creative Commons license, and indicate if changes were made.

\section{References}

Abarca D, Diaz-Sala C (2009) Reprogramming adult cells during organ regeneration in forest species. Plant Signal Behav 4:793-795

Abarca D, Pizarro A, Hernández I, Sánchez C, Solana SP, del Amo A, Carneros E, Díaz-Sala C (2014) The GRAS gene family in pine: transcript expression patterns associated with the maturationrelated decline of competence to form adventitious roots. BMC Plant Biol 14:354

Altamura MM (1996) Root histogenesis in herbaceous and woody explants cultured in vitro. A critical review. Agronomie 16:589-602

Altamura MM, Capitani F, Serafini-Fracassini D, Torrigiani P, Falasca G (1991) Root histogenesis from tobacco thin cell layers. Protoplasma 161:31-42

Auderset G, Moncousin C, O’Rourke J, Morré DJ (1997) Stimulation of root formation in difficult-to-root cuttings by dithiothreitol. Int J Plant Sci 158:132-135

Baima S, Nobili F, Sessa G, Lucchetti S, Ruberti I, Morelli G (1995) The expression of the Athb- 8 homeobox gene is restricted to provascular cells in Arabidopsis thaliana. Development 121:4171-4182

Baima S, Tomassi M, Matteucci A, Altamura MM, Ruberti I, Morelli G (2000) Role of the ATHB-8 gene in xylem formation. In: Savidge RA, Barnett JR, Napier R (eds) Cell and molecular biology of wood formation. BIOS Scientific Publishers, Oxford, pp 445-455

Baima S, Possenti M, Matteucci A, Wisman E, Altamura MM, Ruberti I, Morelli G (2001) The Arabidopsis ATHB-8 HD-zip protein acts as a differentiation-promoting transcription factor of the vascular meristems. Plant Physiol 126:643-655

Baima S, Forte V, Possenti M, Peñalosa A, Leoni G, Salvi S, Felici B, Ruberti I, Morelli G (2014) Negative feedback regulation of auxin signaling by ATHB8/ACL5-BUD2 transcription module. Mol Plant 7:1006-1025

Berlyn GP, Miksche JP (1976) Botanical microtechnique and cytochemistry. Iowa State University Press, Ames

Biondi S, Falasca G, Altamura MM (1994) Histological study of adventitious rooting in vitro of Prunus avium microcuttings. Ann Bot (Roma) 52:21-35
Brugaletta M, La Malfa S, Gentile A, Almeida R, Romano A (2009) In vitro culture establishment of Ceratonia siliqua (L.) mature trees from cultivars of different Mediterranean countries. Acta Hortic 812:113-120

Brunoni F, Rolli E, Dramis L, Incerti M, Abarca D, Pizarro A, Diaz-Sala C, Ricci A (2014) Adventitious rooting adjuvant activity of 1,3di(benzo[ $[d]$ oxazol-5-yl)urea (5-BDPU) and 1,3-di(benzo[ $d]$ oxazol6-yl)urea: new insights and perspectives. Plant Cell Tissue Organ Cult 118:111-124

Busov VB, Yordanov YS, Meilan R (2009) Discovery of genes involved in adventitious root formation using Populus as a model. In: Niemi K, Scagel C (eds) Adventitious root formation of forest trees and horticultural plants-from genes to applications. Research Signpost Publishers, Kerala, pp 85-103

Carlsbecker A, Lee JY, Roberts CJ, Dettmer J, Lehesranta S, Zhou J, Lindgren $\mathrm{O}$, Moreno-Risueno MA, Vatén A, Thitamadee S, Campilho A, Sebastian J, Bowman JL, Helariutta Y, Benfey PN (2010) Cell signalling by microRNA165/6 directs gene dosedependent root cell fate. Nature 465:316-320

Cheng B, Peterson CM, Mitchell RJ (1992) The role of sucrose, auxin and explant source on in vitro rooting of seedling explants of Eucalyptus sideroxylon. Plant Sci 87:207-214

Custodio L, Martins-Loucau MA, Romano A (2004) Influence of sugars on in vitro rooting and acclimatization of carob tree. Biol Plant 48:469-472

da Costa CT, de Almeida MR, Ruedell CM, Schwambach J, Maraschin FS, Fett-Neto AG (2013) When stress and development go hand in hand: main hormonal controls of adventitious rooting in cuttings. Front Plant Sci 4:133

De Klerk G-J (2002) Rooting of microcuttings: theory and practice. In Vitro Cell Dev Biol-Plant 38:415-422

De Klerk G-J, van der Krieken W, De Jong JC (1999) The formation of adventitious roots: new concepts, new possibilities. In Vitro Cell Dev Biol Plant 35:189-199

De Klerk G-J, Hanecakova J, Jasik J (2001) The role of cytokinins in rooting of stem slices cut from apple microcuttings. Plant Biosyst 135:79-84

Della Rovere F, Fattorini L, D’Angeli S, Veloccia A, Falasca G, Altamura MM (2013) Auxin and cytokinin control formation of the quiescent centre in the adventitious root apex of Arabidopsis. Ann Bot 112:1395-1407

Della Rovere F, Fattorini L, D'Angeli S, Veloccia A, Del Duca S, Cai G, Falasca G, Altamura MM (2015) Arabidopsis SHR and SCR transcription factors and AUX1 auxin influx carrier control the switch between adventitious rooting and xylogenesis in planta and in in vitro cultured thin cell layers. Ann Bot 115:617-628

Faivre-Rampant O, Dommes J, Gaspar T, D'Angeli S, Falasca G, Altamura MM (2003) Rooting blockage in the tobacco rac mutant occurs at the initiation phase, and induces diversion to xylem differentiation. Plant Biosyst 137:163-174

Falasca G, Reverberi M, Lauri P, Caboni E, De Stradis A, Altamura MM (2000) How Agrobacterium rhizogenes triggers de novo root formation in a recalcitrant woody plant: an integrated histological, ultrastructural and molecular analysis. New Phytol 145:77-93

Falasca G, Zaghi D, Possenti M, Altamura MM (2004) Adventitious root formation in Arabidopsis thaliana thin cell layers. Plant Cell Rep 23:17-25

Fattorini L, Falasca G, Kevers C, Rocca ML, Zadra C, Altamura MM (2009) Adventitious rooting is enhanced by methyl jasmonate in tobacco thin cell layers. Planta 231:155-168

Fleck JD, Schwambach J, Almeida ME, Yendo ACA, de Costa F, Gosmann G, Fett-Neto AG (2009) Immunoadjuvant saponin production in seedlings and micropropagated plants of Quillaja brasiliensis. In Vitro Cell Dev Biol Plant 45:715-720 
Fukuda H (1997) Tracheary element differentiation. Plant Cell 9:1147-1156

George EF (1993) Plant propagation by tissue culture. Exegetics Ltd, Edington

Grönroos R, von Arnold S (1985) Initiation and development of wound tissue and roots on hypocotyls cuttings of Pinus sylvestris in vitro. Physiol Plant 64:393-401

Hartmann HT, Kester DE, Davies FT (1990) Plant propagation: principles and practices, 5th edn. Prentice Hall, Englewood Cliffs

Helariutta Y, Fukaki H, Wysocka-Diller J, Nakajima K, Jung J, Sena G, Hauser MT, Benfey PN (2000) The SHORT-ROOT gene controls radial patterning of the Arabidopsis root through radial signaling. Cell 101:555-567

Kakani A, Li G, Peng Z (2009) Role of AUX1 in the control of organ identity during in vitro organogenesis and in mediating tissue specific auxin and cytokinin interaction in Arabidopsis. Planta 229:645-657

Koizumi K, Hayashi T, Gallagher KL (2012) SCARECROW reinforces SHORT-ROOT signaling and inhibits periclinal cell divisions in the ground tissue by maintaining SHR at high levels in the endodermis. Plant Signal Behav 7:1573-1577

Legué V, Rigal A, Bhalerao RP (2014) Adventitious root formation in tree species: involvement of transcription factors. Physiol Plant 151:192-198

Li SW, Xue L, Xu S, Feng H, An L (2009) Mediators, genes and signaling in adventitious rooting. Bot Rev 75:230-247

Liu X, Barkawi L, Gardner G, Cohen JD (2012) Transport of indole3-butyric acid and indole-3-acetic acid in Arabidopsis hypocotyls using stable isotope labeling. Plant Physiol 158:1988-2000

McCann MC, Domingo C, Stacey NJ, Milioni D, Roberts K (2000) Tracheary element formation in an in vitro system. In: Savidge RA, Barnett JR, Napier R (eds) Cell and molecular biology of wood formation. BIOS Scientific Publishers, Oxford, pp 457-470

Miyashima S, Sebastian J, Lee JY, Helariutta Y (2013) Stem cell function during plant vascular development. EMBO J 32:178-193

Moubayidin L, Di Mambro R, Sozzani R, Pacifici E, Salvi E, Terpstra I, Bao D, van Dijken A, Dello Ioio R, Perilli S, Ljung K, Benfey PN, Heidstra R, Costantino P, Sabatini S (2013) Spatial coordination between stem cell activity and cell differentiation in the root meristem. Dev Cell 26:405-415

Murashige T, Skoog F (1962) A revised medium for rapid growth and bioassays with tobacco tissue cultures. Physiol Plant 15:473-497

Orlikowska T (1992) Influence of arginine on in vitro rooting of dwarf apple rootstock. Plant Cell Tissue Organ Cult 31:9-14

Pacurar DI, Perrone I, Bellini C (2014) Auxin is a central player in the hormone cross-talks that control adventitious rooting. Physiol Plant 151:83-96

Pesquet E, Jauneau A, Digonnet C, Boudet AM, Pichon M, Goffner D (2003) Zinnia elegans: the missing link from in vitro tracheary elements to xylem. Physiol Plant 119:463-468

Reverberi M, Falasca G, Lauri P, Caboni E, Altamura MM (2001) Indoleacetic acid induces xylem formation instead of rooting in walnut (Juglans regia L.) microcuttings. Plant Biosyst 135:71-77

Ricci A, Carra A, Rolli E, Bertoletti C, Branca C (2003) N,N'-bis(2,3-methylenedioxyphenyl)urea and $\mathrm{N}, \mathrm{N}^{\prime}$-bis-(3,4-methylenedioxyphenyl)urea interact with auxin in enhancing root formation of M26 apple (Malus pumila Mill.) stem slices. Plant Growth Regul 40:207-212

Ricci A, Incerti M, Rolli E, Vicini P, Morini G, Comini M, Branca C (2006) Diheteroarylurea derivatives as adventitious rooting adjuvants in mung bean shoots and M26 apple rootstock. Plant Growth Regul 50:201-209

Ricci A, Rolli E, Dramis L, Diaz-Sala C (2008) N,N'-bis-(2,3Methylenedioxyphenyl)urea and N,N'-bis-(3,4-methylenedioxyphenyl)urea enhance adventitious rooting in Pinus radiata and affect expression of genes induced during adventitious rooting in the presence of exogenous auxin. Plant Sci 175:356-363

Romano A, Barros S, Martins-Loução MA (2002) Micropropagation of the Mediterranean tree Ceratonia siliqua. Plant Cell Tissue Organ Cult 68:35-41

Rugini E, Jacoboni A, Luppino M (1993) Role of basal shoot darkening and exogenous putrescine treatments on in vitro rooting and on endogenous polyamine changes in difficult-toroot woody species. Sci Hortic 53:63-72

Sakcali MS, Ozturk M (2004) Eco-physiological behavior of some mediterranean plants as suitable candidates for reclamation of degraded areas. J Arid Environ 57:1-13

Sánchez C, Vielba JM, Ferro E, Covelo G, Solé A, Abarca D, de Mier BS, Díaz-Sala C (2007) Two SCARECROW-LIKE genes are induced in response to exogenous auxin in rooting-competent cuttings of distantly related forest species. Tree Physiol 27:1459-1470

Schmitz RY, Skoog F (1970) The use of dimethylsulfoxide as a solvent in the tobacco bioassay for cytokinins. Plant Physiol 45:537-538

Sebastian KT, McComb JA (1986) A micropropagation system for carob (Ceratonia siliqua L.). Sci Hortic 28:127-131

Solé A, Sánchez C, Vielba JM, Valladares S, Abarca D, Díaz-Sala C (2008) Characterization and expression of a Pinus radiata putative ortholog to the Arabidopsis SHORT-ROOT gene. Tree Physiol 28:1629-1639

Sundberg B, Uggla C, Tuominen H (2000) Cambial growth and auxin gradients. In: Savidge RA, Barnett JR, Napier R (eds) Cell and molecular biology of wood formation. BIOS Scientific Publishers, Oxford, pp 169-188

Tran Thanh Van M, Dien NT, Chlyah A (1974) Regulation of organogenesis in small explants of superficial tissue of Nicotiana tabacum L. Planta 119:149-159

Van Staden J, Harty AR (1988) Cytokinins and adventitious root formation. In: Davis TD, Haissig BE, Sankla N (eds) Adventitious root formation in cuttings. Advances in Plant Sciences Series, vol 2. Dioscorides Press, Portland, pp 185-201

Vielba JM, Díaz-Sala C, Ferro E, Rico S, Lamprecht M, Abarca D, Ballester A, Sánchez C (2011) CsSCL1 is differentially regulated upon maturation in chestnut microshoots and is specifically expressed in rooting-competent cells. Tree Physiol 31:1152-1160

Welander M, Huntrieser I (1981) The rooting ability of shoots raised in vitro from the apple rootstock A2 in juvenile and in adult growth phase. Physiol Plant 53:301-306

Welander M, Geier T, Smolka A, Ahlman A, Fan J, Zhu LH (2014) Origin, timing, and gene expression profile of adventitious rooting in Arabidopsis hypocotyls and stems. Am J Bot 101:255-266 